\title{
Penentuan Karakteristik Minyak Ikan Sidat Hasil Nelayan Kabupaten Cilacap Sebagai Bahan Baku Sediaan Farmasi Terstandar
}

\author{
Anita Ratna Faoziyah
}

\begin{abstract}
Anguilla bicolor is an eel found in Cilacap. The purpose of this research is the characteristics of fish oil eels from Cilacap. The eel contain vitamin A, B1, B2, zinc (Zn), unsaturated fatty acids such as docosahexaenoic acid (DHA), eicosapentaenoic acid (EPA) and antioxidants. Eel oil has a boiling point of $157^{\circ} \mathrm{C}$ and freezing point $4^{\circ} \mathrm{C}$, soluble in non-polar solvents such as hexane and chloroform, acid number $1.54 \mathrm{mg} \mathrm{KOH} / \mathrm{g}$, iod number of $61.44 \mathrm{ppm}$ and saponification number 253,011 mgKOH/g . The functional groups of eel oil compounds is carbonyl groups $(C=0): 1650-1750 \mathrm{~cm}-1$, hydroxyl $(\mathrm{OH}): 2500-3000 \mathrm{~cm}-$ 1, ester (CO): $1000-1300 \mathrm{~cm}-1$, aldehyde (CH) : $1760 \mathrm{~cm}-1$. Fatty acids with contain in eel oil is palmitic acid $24,72 \%$, linoleate acid $4,84 \%$, oleic acid $47,65 \%$ and decosahexaenoic acid equal to $8,67 \%$. The analysis results showed eel oil heavy metals $\mathrm{Pb}$ (lead) less than 0.0096 and $\mathrm{Cd}$ (cadmium) less than 0.01 so the eel is safe to consume and can be used as raw materials for pharmaceutical or pharmaceuticalbased maritime of pharmacy .
\end{abstract}

Keyword: Eel, Fatty acid, Albumin, Marine of pharmacy.

\section{Intisari}

Anguilla bicolor merupakan ikan sidat yang terdapat di Kabupaten Cilacap. Tujuan penelitian ini adalah mengetahui karakteristik minyak ikan sidat hasil nelayan Kabupaten Cilacap. Kandungan daging ikan sidat meliputi vitamin A,B1,B2, zeng (Zn), asam lemak tak jenuh seperti docosahexaenoic acid (DHA), eicosapentaenoic acid (EPA) dan antioksidan. Minyak ikan sidat memiliki titik didih $157^{\circ} \mathrm{C}$ dan titik beku $4^{\circ} \mathrm{C}$, minyak ikan sidat dapat larut pada pelarut non polar seperti hexana dan kloroform, bilangan asam $1,54 \mathrm{mg} \mathrm{KOH} / \mathrm{g}$, bilangan iod sebesar $61,44 \mathrm{ppm}$ dan bilangan penyabunan 253,011 mgKOH/g. Gugus fungsi senyawa minyak ikan sidat meliputi gugus karbonil (C=O) :1650-1750 cm-1, hidroksil (OH) : 2500$3000 \mathrm{~cm}-1$, ester (C-O) : 1000-1300 cm-1, aldehid (C-H) : $1760 \mathrm{~cm}-1$. Asam lemak yang terdapat dalam minyak ikan sidat terdiri dari asam palmitat $24,72 \%$, asam linoleate $4,84 \%$, asam oleat $47,65 \%$ dan asam decosahexaenoic sebesar $8,67 \%$. Analisis logam berat $\mathrm{Pb}$ (timbal) dan $\mathrm{Cd}$ (cadmium) terkadung pada minyak ikan sidat sebesar $\mathrm{Pb}$ kurang dari 0.0096 dan $\mathrm{Cd}$ kurang dari 0,01 sehingga menunjukan ikan sidat aman dikomsumsi dan dapat digunakan sebagai bahan baku sediaan farmasi atau pangan fungsional berbasis farmasi bahari.

Kata Kunci : Ikan sidat, Asam lemak, Albumin, Farmasi bahari

\section{Afiliasi Penulis}

Prodi D3 Farmasi STIKES Al-Irsyad Al-Islamiyyah Cilacap

Korespondensi kepada

A.R. Faoziyah

anitahendrayatno@gmail.com

\section{Pendahuluan}

Ikan sidat yang terdapat di Kabupaten Cilacap terdiri dari dua spesies ikan sidat yaitu ikan sidat spesies Anguilla bicolor dan Anguilla marmorata (Affandi, R. 2011). Ikan sidat merupakan jenis ikan karnivora (pemakan daging) yang memiliki pola daur hidup katadromous artinya mengawali di laut, 
tumbuh menjadi dewasa di perairan tawar dan akan kembali ke laut untuk memijah, selain memiliki pola hidup yang unik bentuk ikan sidat juga memiliki bentuk tubuh yang memanjang menyerupai ular (Fahmi \& Himewati, 2010).

Lendir ikan sidat dapat digunakan sebagai anti bakteri kelompok protease seperti cathepsins $L$ dan B (Ebral, 2010. Selain itu efektifitas lendir sidat dalam menghambat pertumbuhan bakteri Salmonella thyposa dengan daya hambat pertumbuhan bakteri S.thyposa sebesar $41,08 \%$ (Indriatmoko, 2010). Lendir sidat juga dimanfaatkan untuk pengobatan tradisional seperti pengobatan pada luka (Roy, 2013). Selain itu daging ikan sidat juga banyak mengandung protein albumin yang dapat digunakan sebagai nutrisi penyembuahan luka operasi. Albumin berfungsi untuk mengatur tekanan osmotik dalam darah dan juga sebagai sarana pengangkut atau transportasi. Albumin bermanfaat dalam pembentukan jaringan tubuh yang baru pada masa pertumbuhan dan dapat mempercepat penyembuhan jaringan tubuh (Suprayitno, 2009; Poedjiadi, 2006). Pengujian secara ilmiah yang dilakukan oleh Sinambela (2012), menyatakan bahwa ikan gabus yang mengandung albumin memiliki aktivitas dan efektivitas terhadap penyembuhan luka sayat dimana sediaan salep minyak ikan gabus pada konsentrasi $10 \%$ dapat memberikan hasil terbaik terhadap penutupan luka sayat dengan luka menutup hari ke-8. Ikan sidat memiliki kandungan protein albumin yang tinggi dan baik untuk kesehatan (Aida, dkk., 2003). Ikan sidat juga memiliki kandungan minyak ikan yang tinggi dan kaya kandungan senyawa kimia. Untuk $3 \mathrm{~kg}$ ikan sidat spesies Anguilla bicolor mengandung $250 \mathrm{ml}$ minyak ikan sidat, sedangkan pada ikan sidat spesies Anguilla marmorata mengadung $50 \mathrm{ml}$ lebih sedikit dari pada spesies Anguilla bicolor (Fauziah, 2014)

\section{Metode}

\section{Bahan}

Minyak ikan sidat spesies ikan sidat yang terdapat di perairan payau Kabupaten Cilacap (Angguila bicolor),etanol 96\%, $\mathrm{KOH}$, $\mathrm{KI}$, Larutan $\mathrm{Na}_{2} \mathrm{~S}_{2} \mathrm{O}_{3} .5 \mathrm{H} 2 \mathrm{O}$ (tiosulfat), kloroforom, N-heksana, asam asetat gliseral.

\section{Alat}

Timbangan analitik, alat-alat gelas kimia, erlemeyer, piknometer, $\mathrm{pH}$ meter, magnetic heater stirer, piknometer.

\section{Analisis Minyak Ikan Sidat}

Penelitian ini dilakukan dengan mengunakan beberapa tahap yaitu: Tahap pertama merupakan uji sifat fisika kimia minyak ikan sidat yang terdiri dari uji organoleptis, uji bobot jenis minyak, uji kelarutan, uji pengukuran titik beku dan titik didih, uji bilangan asam dan uji bilangan peroksida. Sedangkan pada tahap kedua dari penelitian adalah analisis kandungan logam berat dengan mengunakan alat spektrofotometer serapan atom (AAS) dan analisis kandungan asam lemak yang terdapat dalam minyak ikan sidat dengan mengunakan alat kromatografi gas spectra massa (GC-MS).

\section{Hasil \& Pembahasan}

Hasil uji organoleptis ikan sidat spesies Anguilla bicolor diperoleh warna minyak ikan sidat kuning kecoklatan, berbau amis dan tidak berasa. Bobot jenis minyak ikan sidat sebesar $0,935 \mathrm{gr} / \mathrm{cm} 3$. Hasil uji kelarutan minyak ikan sidat spesies anguilla bicolor dengan beberapa pelarut dapat dilihat pada Tabel 1.

Berdasarkan hasil uji kelarutan minyak ikan sidat hanya larut dipelarut-pelarut non polar yaitu heksana dan kloroform, sedangakan pada pelarut semi polah hanya larut sebagian. Metode yang digunakan dalam uji kelarutan minyak ikan sidat mengunakan metode ekstraksi cair cair dengan penambahan dan distribusi pelarut. Pada ekstraksi minyak ikan sidat dengan pelarut polar minyak ikan sidat tidak larut, pelarut semi polar minyak ikan sidat sedikit larut dan pada pelarut non polar
Tabel 1 | Hasil uji kelarutan minyak ikan sidat (Anguilla Bicolor)

No Pelarut Kelarutan

$\begin{array}{lll}1 & \text { Etanol } & \text { Tidak Larut } \\ 2 & \text { Aseton } & \text { Larut Sebagian } \\ 3 & \text { Metanol } & \text { Tidak Larut (Minyak di bawah pelarut) } \\ 4 & \text { Hexana } & \text { Larut Sempurna } \\ 5 & \text { Chloroform } & \text { Larut Sempurna } \\ 6 & \text { Larutan } \mathrm{NaCl} & \text { Tidak larut (Minyak di atas pelarut) }\end{array}$


minyak ikan sidat larut sempurna. hasil uji kelarutan minyak ikan sidat mengikuti prinsip kerja ekstraksi yaitu like dissolved like pelarut yang bersifat polar hanya akan melarutkan senyawa polar dan pelarut non polar hanya akan larut pada senyawa yang bersifat non polar (Ebran $\mathrm{N}$ dkk, 2000).

Uji karakteristik sifat fisika kimia minyak ikan ikan sidat dilakukan dengan menentukan titik didih dan titik beku. Minyak ikan sidat memeiliki titik didik sebesar $157^{\circ} \mathrm{C}$, dan titik beku $4^{\circ} \mathrm{C}$. Hal ini sesuai dengan habitat hidup dari ikan sidat yang mengalami proses hidup dari telur sampai kecil hidup di air payau dengan suhu air payau sebanding dengan suhu udara, dan apabila ikan sidat sudah mencapai dewasa akan berpindah ke laut yang memiliki suhu air lebih dingin apabila dibandingkan dengan suhu di perairan payau (Matsui, 1970). Hasil penentuan karakteristik sifat kimia minyak ikan sidat dapat ditentukan dengan uji bilangan asam, uji bilangan peroksida (iod), uji bilangan penyabunan, analisis gugus fungsi senyawa yang terkandung pada minyak ikan sidat dan uji kandungan asam lemak yang terdapat dalam minyak ikan sidat.

Analisis bilangan asam dipergunakan untuk mengukur jumlah asam lemak bebas yang terdapat dalam minyak. Bilangan Peroksida (iod) merupakan bilangan yang dapat menunjukkan nilai ketidakjenuhan asam lemak penyusun minyak. Asam lemak tak jenuh mampu mengikat iod dan membentuk senyawa yang jenuh. Banyaknya iod yang diikat menunjukan banyaknya ikatan rangkap yang terkandung pada minyak ikan sidat. Asam lemak jenuh banyak terdapat pada minyak yang berwujud padat sedangkan minyak cair memiliki kandungan asam lemak tak jenuh lebih tinggi. Hasil penelitian analisis bilangan peroksida pada minyak ikan sidat sebesar $61,44 \mathrm{ppm}$. Hal ini menunjukan bahwa kandungan minyak ikan sidat memiliki banyak senyawa asam lemak jenuh sehingga dapat menunjukan banyaknya ikatan rangkat yang terapat dalam minyak ikan sidat. Langkah selanjutnya dalam penentuan karakteristik minyak ikan sidat adalah penentuan bilangan penyabunan. Penentuan bilangan penyabunan pada karakteristik minyak ikan sidat bertujuan untuk mengetahui banyaknya alkali yang butuhkan dalam melakukan reaksi penyabunan. Bilangan penyabunan dinyatakan dalam jumlah milligram kalium hidroksida yang dibutuhkan untuk melakukan reaksi penyabunan $1 \mathrm{gr}$ minyak. Hasil uji bilangan penyabunan pada minyak ikan sidat diperoleh bilangan penyabunan sebesar 253,011 $\mathrm{mgKOH} / \mathrm{g}$. Besarnya bilangan penyambunan bergantung dari berat molukul senyawa-senyawa yang terkandung dalam minyak ikan.minyak dengan kandungan senyawa yang memiliki bobot molekul rendah akan mempunyai bilangan penyabunan yang lebih tinggi dari pada minyak yang memiliki bilangan molekul tinggi. Minyak ikan sidat juga mengandung beberapa asam lemak yang tinggi dan dapat digunakan sebagai nutrisi pertumbuhan.

Kandungan gizi yang terdapat pada ikan sidat meliputi vitamin A, B1, B2, Seng (Zn) dan kandungan asam lemak tak jenuh seperti docosahexaenoic acid (DHA), eicosapentaenoic

\begin{tabular}{|c|c|c|}
\hline No & Pelarut & Kelarutan \\
\hline 1 & Bilangan asam & $1,54 \mathrm{mg} \mathrm{KOH} / \mathrm{gr}$ \\
\hline 2 & Bilangan Peroksida (lod) & 61,44 ppm \\
\hline 3 & Bilangan Penyabunan & 253,011 mgKOH/g. \\
\hline 4 & Gugus fungsi senyawa organik & $\begin{array}{l}\text { Karbonil }(\mathrm{C}=\mathrm{O}): 1650-1750 \mathrm{~cm}-1 \text {, } \\
\text { Hidroksil }(\mathrm{OH}): 2500-3000 \mathrm{~cm}-1 \text {, } \\
\text { Ester }(\mathrm{C}-\mathrm{O}): 1000-1300 \mathrm{~cm}-1 \text {, } \\
\text { Aldehid }(\mathrm{C}-\mathrm{H}): 1760 \mathrm{~cm}-1\end{array}$ \\
\hline 5 & Senyawa asam lemak & $\begin{array}{l}\text { Asam palmitat }=24,72 \% \\
\text { Asam linoleat }=4,84 \% \\
\text { Asam oleat }=47,65 \% \\
\text { Asam Decosahexaenoat }=8,67 \%\end{array}$ \\
\hline
\end{tabular}


Tabel 3 | Hasil uji kandungan logam berat minyak ikan sidat (Anguilla Bicolor) yang diperoleh dari perairan payau kabupaten Cilacap

\begin{tabular}{rll} 
No & Logam berat & Hasil \\
\hline 1 & $\mathrm{~Pb}$ (timbal) & $<0.0096$ \\
2 & $\mathrm{Cd}$ (kadmium) & $<0,01$
\end{tabular}

acid (EPA) dan anti oksidan yang terdapat pada sumsum sidat (Aranishi,2000). DHA merupakan lemak tak jenuh yang dapat menurunkan lemak darah dalam tubuh manusia. EPA merupakan asam lemak jenuh yang di kenal dengan omega-3 sedangkan anti oksidan dapat merangsang terbentuknya sel imunitas, meningkatkan aktivitas sel imunitas, memperkuat fungsi imunitas dan membersikan radikan bebas di dalam sel. Selain itu AKG dapat berfungsi untuk meningkatkan jumlah sel darah putih, sel limpa dan keping darah (trombosit) (Suitha \& Suheri, 2012).

Berdasarkan hasil analisis kandungan logam berat minyak ikan sidat yang diperoleh dari perairan payau Kabupaten Cilacap tidak terkontaminasi dengan logam berat $\mathrm{Pb}$ dan $\mathrm{Cd}$ (tabel 3), hal ini menunjukkan bahwa letak perairan payau yang berdekatan dengan kawasan industri Kabupaten Cilacap tidak mempengaruhi dari kandungan gizi biota laut khususnya ikan sidat yang terdapat di perairan payau Kabupaten Cilacap.

Selain tidak ditemukannya kandungan logam berat yang berbahaya pada ikan sidat, ikan sidat juga memiliki kandungan asam lemak yang tinggi seperti asam palmitat $24,72 \%$, asam linoleate $4,84 \%$, asam oleat $47,65 \%$ dan asam decosahexaenoic sebesar $8.67 \%$. Asam lemak merupakan senyawa golongan asam karboksilat yang mempunyai rantai alifatik Panjang, baik jenuh maupun yang tidak jenuh. Hasil analisis kandungan asam lemak yang terdapat dalam ikan sidat adalah jenis asam lemak tak jenuh yang sangat penting (essensial) bagi kesehatan tubuh dan merupakan jenis asam lemak penyusun omega-3, dan omega 9.

\section{Kesimpulan}

Karakteristik minyak ikan sidat memiliki titik didih $157^{\circ} \mathrm{C}$ dan titik beku $4^{\circ} \mathrm{C}$, minyak ikan sidat dapat larut dipelarut non polar seperti hexana dan kloroform, minyak ikan sidat memiliki bilangan asam 1,54 mg KOH/gr, bilangan iod sebesar 61,44 ppm dan bilangan penyabunan 253,011 $\mathrm{mgKOH} / \mathrm{g}$

Gugus fungsi yang terdapat dalam minyak ikan sidat spesies Anguilla bicolor meliputi karbonil (C=O) : 1650-1750 $\mathrm{cm}^{-1}$, hidroksil (OH) : 2500-3000 $\mathrm{cm}^{-1}$, ester (C-O) : 1000-1300 $\mathrm{cm}^{-1}$, aldehid (C-H) : $1760 \mathrm{~cm}^{-1}$.

Kandungan asam lemat yang terdapat dalam minyak ikan sidat meliputi Asam palmitat $=24,72 \%$, Asam linoleate $=4,84 \%$, Asam oleat $=47,65 \%$ dan Asam Decosahexaenoic $=8,67 \%$.

Analisis logam berat $\mathrm{Pb}$ (timbal) dan $\mathrm{Cd}$ (cadmium) terkadung pada minyak ikan sidat sebesar Pb kurang dari 0.0096 dan Cd kurang dari 0,01 sehingga menunjukan ikan sidat aman dikomsumsi dan dapat digunakan sebagai bahan baku sediaan farmasi

\section{Bibliografi}

1. Baccelli, I., Schneeweiss, A., Riethdorf, S., Stenzinger, A., Schillert, A., Vogel, V., ... Trumpp, A. (2013). Identification of a population of blood circulating tumor cells from breast cancer patients that initiates metastasis in a xenograft assay. Nature biotechnology, 31(6), 539-44.

2. Affandi, R. (2005). Strategi Pemanfaatan Sumberdaya Ikan Sidat Anguilla spp di Indonesia, Departemen Manajemen Sumberdaya Perairan, FPIK-IPB

3. Aida, K., Tsukamoto, K., \& Yamauchi, K. (2003). Eel Biology, Springer, Tokyo.

4. Aranishi $F(2000)$ High sensitivity of skin cathepsins $L$ and $B$ of European eel Anguilla anguilla to thermal stress. Aquaculture 182:209-213

5. Bigelow L., 2002 "Fishes of the Gulf of Maine, Fishery Bulletin of the Fish and Wildlife Service" Washington

6. Ebran N, Julien S, Orange N, Auperin B, Molle G (2000) Isolation and characterization of novel glycoproteins from fish epidermal mucus: correlation between their poreforming properties and their antibacterial activities. Biochimica et Biophysica Acta1467:271-280.

7. Fahmi R.M \& Himawati R, 2010" Keragaman Ikan Sidat Tropis (Anguilla sp.) di perairan sungai Cimandiri Pelabuhan Ratu Sukabumi" Prosiding Forum Inovasi Teknologi Akuakultur

8. Faoziyah.,2014 "Analisis Kandungan Asam Lemak Pada Beberapa Spesies Ikan Sidat yang terdapat di Perairan Payau Kabupaten Cilacap" STIKES Al-Irsyad Al-Islamiyyah Cilacap

9. Indriatmoko S, 2011"Uji Efektifitas Lendir Ikan Sidat 
terhadap Bakteri Salmonella Typhii" STIKES Al-Irsyad Al-Islamiyyah Cilacap

10. Matsui, I.,2010. Theory and Practice of Eel Culture (Aquaculture Seri 4). Amerind Publishing Co. Pct.Ltd,New Delhi,Bombay, Calcuta, New York, 133p.

11. Roy, R. (2013). Budi Daya Sidat, Penerbit Agromedia Pustaka, Jakarta

12. Sinambela. H.Y. (2012). Optimasi Formulasi Sediaan Salep Minyak Ikan Gabus (Channa Striata Bloch) sebagai Obat Luka Sayat dengan Metode Simplex Lattice Design, Skripsi, Program Studi Farmasi, Fakultas Kedokteran Universitas Tanjungpura Pontianak.

13. Suprayitno. E. (2009). Penggunaan Albumin Ikan Gabus pada Penutupan Luka, Artikel IImiah, 1(2) : 1 